\title{
Bioaccumulations of heavy metals in submerged macrophytes in the mountain river Biała Lądecka (Poland, Sudety Mts.)
}

\author{
Przemysław Pokorny ${ }^{1 *}$, Joanna Pokorny², Wojciech Dobicki ${ }^{1}$, Magdalena Senze ${ }^{1}$, \\ Monika Kowalska-Góralska ${ }^{1}$
}

\author{
${ }^{1}$ University of Environmental and Life Sciences in Wrocław, Poland \\ Department of Hydrobiology and Aquaculture \\ ${ }^{2}$ University of Environmental and Life Sciences in Wrocław, Poland \\ Department of Botany and Plant Ecology
}

*Corresponding author's e-mail: przemyslaw.pokorny@up.wroc.pl

\begin{abstract}
Keywords: bioaccumulation, heavy metals, submerged plants, Sudety Mts., mountain rivers, Biała Lądecka River.
Abstract: The study was conducted on the Biała Lądecka River which is a mountain river. It is similar to many European mountain rivers in terms of hydromorphology and catchment management. The aim of this study was to determine the bioconcentration factors of heavy metals ( $\mathrm{Pb}, \mathrm{Cd}, \mathrm{Hg}, \mathrm{Ni}, \mathrm{Cr}, \mathrm{Cu}$ and $\mathrm{Zn}$ ) in Ranunculus aquatile (L.) Dumort., Fontinalis antipyretica (L. ex Hedw.), and Lemanea fluviatilis (L.) C.Ag. The content of metals in water, sediment, and submerged plants was determined. The metal concentrations in plants can be arranged as follows: $\mathrm{Hg}<\mathrm{Cd}<\mathrm{Cr}<\mathrm{Ni}<\mathrm{Cu}<\mathrm{Pb}<\mathrm{Zn}$. The highest concentrations of $\mathrm{Hg}, \mathrm{Ni}, \mathrm{Cr}$, and $\mathrm{Cu}$ were observed in $F$. antipyretica, but the highest concentrations of $\mathrm{Pb}, \mathrm{Cd}$, and $\mathrm{Zn}$ were in $R$. aquatile. L. fluviatilis always contained the least amounts of heavy metals. Bioconcentration factors (BCFs) were lowest in L. fluviatilis and highest in F. antipyretica. Among the analyzed metals, plants accumulated the highest amount of $\mathrm{Zn}$, and the least of Hg. The BCFs for Zn were from 24111 (in L. fluviatilis) to 97574 (in R. aquatile), and BCFs for Hg were from 29 (in L. fluviatilis) to 226 (in F. antipyretica).
\end{abstract}

\section{Introduction}

Water pollution is a fact. We are looking for better (cheaper, easier, faster, more accurate) methods for assessing contamination. A particular challenge is to assess the pollution in the fast-flowing waters of mountain rivers. High flow rates result in a change in the content of pollutants in the water.

Macrophytes have proved to be good material for the study since they are easy to obtain and prepare for testing. Among the aquatic plants, submerged plants deserve special attention. Due to the physiology of submerged plants, they may accumulate the largest amounts of pollutants (Senze et al. 2009).

We wanted to make our study as universal as possible. For this reason, we chose for the study the Biała Lądecka river which is a typical European mountain river. The Biała Lądecka River is a right tributary of the Nysa Kłodzka River, with a length of $53 \mathrm{~km}$ and a basin area of $314.6 \mathrm{~km}^{2}$. The Biała Lądecka River begins in the Bialskie Mountains at an altitude of 1090 meters above sea level and turns into the Nysa Kłodzka River at its $133.1 \mathrm{~km}$ in the village of Krosnowice at 236 meters above sea level. The river basin is dominated by forests, extensive agriculture as well as urban development. Pollution is prominent because of the crystal glass factory, municipal sewage treatment plants and numerous trout farms. The middle-part of the river $(16.3 \mathrm{~km})$ is designated as a Special Protected Area "PLH020035 Biała Lądecka" under the Natura 2000 network.

The study involved macrophytes commonly found in the Biała Lądecka River. There are dominant submerged species of macrophytes in this river, representing different systematic groups of plants.

Ranunculus aquatile (L.) Dumort. is a species representing a group of Angiosperms Cronquist., of the family Ranunculaceae (Juss.). Ranunculus aquatile (L.) Dumort. is a perennial plant and hydrophyte. This plant blooms from April to August. It occurs in shallow and slow-flowing water and canals (Cook 1963, Dahlgren 1991). Ranunculus (L.) subgenus Batrachium (DC.) A. Gray - Batrachium was first treated as a subgenus by A. Gray in 1886 but the rank has varied from section to genus (Dahlgren, 1991). Cook (1963) found the subgenus rank to be the most appropriate. The subgenus is mainly located in Atlantic European countries. All species except two occur in Europe. The subgenus Batrachium has 17 species (Dahlgren 1991).

Fontinalis antipyretica (L. ex Hedw.) is a taxon representing the subclass Bryidae. It occurs in Europe, North Asia, northern Africa and North America, in clear-flowing or 
standing waters. This moss is common throughout Poland. It grows on underwater rocks, stones, and pieces of wood in shady places. F. antipyretica is often found in temperate regions, in flowing freshwater streams and ponds. Of the 20 species of water moss, 18 are native to North America. A brook moss may have shoots 30 to 100 (rarely up to 200) cm long and is usually attached to a stone or a tree root. The most common species is F.antipyretica. This species has long, slender branches covered with glossy, yellowish green or dark green phyllids (leaves), 4 to $7 \mathrm{~mm}$ long and arranged in three ranks. Male and female reproductive organs are on separate plants (Atherton et al. 2010).

Lemanea fluviatilis (L.) C.Ag. is a species representing the division Rhodophyta, of the order Batrachospermales (Bory de Saint-Vincent 1808). This taxon occurs in Europe (Kučera et al. 2004), in North America (Vis et al. 1992), South America and Australia. The freshwater red algae of the family Lemaneaceae are characterized by an uniaxival cartilagineous and pseudoparenchymatous gametophyte thallus with internal carposporophytes (Vis et al. 1992). In Poland, the species occurs in several places especially in the southern part of the country (Starmach 1977). There is only a small-number of locations with the species L. fluviatilis since it needs specific ecological conditions. For this reason, this alga is on the red list, in those countries where this species is defined as vulnerable (Siemińska 2006).

The first aim of this study was to determine the bioconcentration factors (BCFs) for heavy metals $(\mathrm{Pb}, \mathrm{Cd}$, $\mathrm{Hg}, \mathrm{Ni}, \mathrm{Cr}, \mathrm{Cu}$ and $\mathrm{Zn}$ ) in Ranunculus aquatile (L.) Dumort., Fontinalis antipyretica (L. ex Hedw.), and Lemanea fluviatilis (L.) C.Ag. The second aim was to investigate whether the bioconcentration factors depend on basic physicochemical parameters of water as well as the concentration of heavy metals in water and sediment.

\section{Materials and methods}

The research was conducted in 2005, in the section of the river that runs from the mouth (in Krosnowice) to the village of Stary Gierałtów. Samples of water, sediment, and plants were taken at 9 points (Fig 1), three times a year (in the spring, summer and autumn). Coordinates of sampling sites were determined using GPS map 76CS (GARMIN).

The following physicochemical parameters were determined: temperature $\left({ }^{\circ} \mathrm{C}\right)$, electrolytic conductivity $\left(\mu \mathrm{S} \cdot \mathrm{cm}^{-1}\right)$, water $\mathrm{pH}$, dissolved oxygen $\left(\mathrm{mgO}_{2} \cdot \mathrm{dm}^{-3}\right)$, water alkalinity $\left(\mathrm{mgCaCO}_{3} \cdot \mathrm{dm}^{-3}\right)$, water hardness $\left(\mathrm{mgCaCO}_{3}\right.$. $\mathrm{dm}^{-3}$ ), and the biochemical oxygen demand over 5 days $-\mathrm{BOD}_{5}$ $\left(\mathrm{mgO}_{2} \cdot \mathrm{dm}^{-3}\right)$.

The sediment samples and plants were "wet" mineralized in a pressure microwave oven MARS 5 (CEM Corporation, USA). The sediment samples were mineralized with a mixture of $\mathrm{HNO}_{3}$ and $\mathrm{HClO}_{4}$ at $3 \div 1$, and the plants with $\mathrm{HNO}_{3}$.

The amount of metals in mineralizate were determined using atomic absorption spectrophotometry (AAS). The flame method (SpectrAA 220 - Varian, Australia) was used to determine $\mathrm{Pb}, \mathrm{Cd}, \mathrm{Ni}, \mathrm{Cr}, \mathrm{Cu}$, and $\mathrm{Zn}$. The cold vapor method (TMA 254 - Tesla, the Czech Republic) was used to determine $\mathrm{Hg}$.

The results of the analyses were verified with the certified reference materials: BCR 60 (Commission of the European Communities, Community Bureau of Reference) - aquatic plant Lagarosiphon major and CRM 482 (Commission of the European Communities, Community Bureau of Reference)

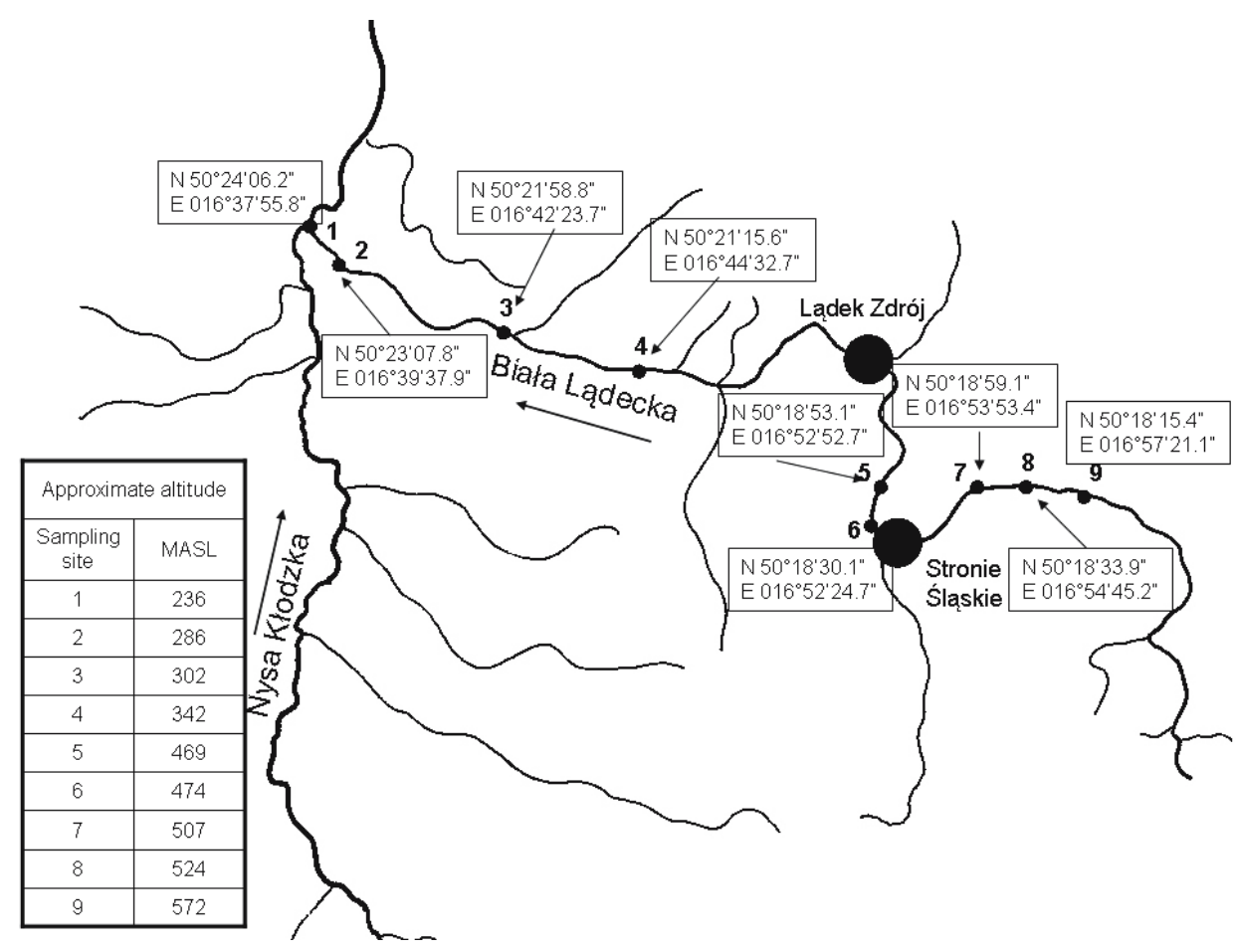

Fig. 1. Location of sampling site on Biała Lądecka River

MASL - meters above sea level 
- Pseudevernia furfuracea, LGC 6187 (Laboratory of the Government Chemistry) - river sediments. Certified values for the reference materials used and the obtained concentrations ( 5 replicates) are summarized in Table 1.

The accuracy of the method was understood as the difference between the real value of the studied indicator, and the average value of the obtained measurement that was below $5 \%$.

Metal concentrations in the deposits and metal concentrations in the plants are presented in $\mathrm{mg} \cdot \mathrm{kg}^{-1}$ of dry weight, in water in $\mu \mathrm{g} \cdot \mathrm{dm}^{-3}$.

The bioconcentration factors (BCFs) were calculated as the relationship of metal concentration in the plant to the concentration of metal in water.

The statistical analysis of the results (the minima, the maxima, the mean, the standard deviation, differences, correlations) was carried out using Statistica 10.0 (StatSoft).

\section{Results}

The recorded physical and chemical indicators of water quality are summarized in Table 2. According to the current classification in Poland, the physical and chemical water parameters in the tested section, classified the Biała Lądecka River as having a class I freshwater quality.

The $\mathrm{pH}$ of the water of the Biała Lądecka River was slightly alkaline (pH 6.9-8.1). Electrolytic conductivity of the water and its total hardness were relatively low. The content of dissolved $\mathrm{O}_{2}$ was high, which is typical for the fast- running and stirred-up water of mountain streams and rivers. Average $\mathrm{BOD}_{5}$ was low, but its maximum value was high. These results may indicate water contamination with organic substances.

The metal contents which were found in the water of the Biała Ladecka River are shown in Table 3. Different levels of metals were found in the water from $0.57 \mu \mathrm{g} \cdot \mathrm{dm}^{-3}$ $(\mathrm{Hg})$ to $8.43 \mu \mathrm{g} \cdot \mathrm{dm}^{-3}(\mathrm{Zn})$. According to Kabata-Pendias et al. (1993), $\mathrm{Pb}, \mathrm{Ni}, \mathrm{Cr}, \mathrm{Cu}$, and $\mathrm{Zn}$ concentrations are characteristic for Polish rivers, while concentrations of $\mathrm{Hg}$ and $\mathrm{Zn}$ indicate contamination.

The contents of five metals $-\mathrm{Pb}, \mathrm{Hg}, \mathrm{Ni}, \mathrm{Cu}$ i $\mathrm{Zn}$ were examined in sediment (Table 4). The concentration of $\mathrm{Hg}$ in the sediment was lowest $\left(0.03 \mathrm{mg} \cdot \mathrm{kg}^{-1}\right)$. Concentrations of $\mathrm{Cu}$ and $\mathrm{Ni}$ were considered to be at the middle level (13.78 and $14.71 \mathrm{mg} \cdot \mathrm{kg}^{-1}$, respectively), while the concentration of $\mathrm{Zn}$ in the sediment was highest $\left(74.24 \mathrm{mg} \cdot \mathrm{kg}^{-1}\right)$.

Table 1. Certified and obtained concentration of $\mathrm{Pb}, \mathrm{Cd}, \mathrm{Hg}, \mathrm{Ni}, \mathrm{Cr}, \mathrm{Cu}$ and $\mathrm{Zn}$ in used reference materials $\left(\mathrm{mg} \cdot \mathrm{kg}^{-1}\right)$

\begin{tabular}{|l|c|c|c|c|c|c|c|}
\hline & $\mathrm{Pb}$ & $\mathrm{Cd}$ & $\mathrm{Hg}$ & $\mathrm{Ni}$ & $\mathrm{Cr}$ & $\mathrm{Cu}$ & $\mathrm{Zn}$ \\
\hline $\begin{array}{l}\text { CRM 482 } \\
\text { certificated }\end{array}$ & 40.900 & 0.560 & 0.480 & 2.470 & 4.120 & 7.030 & 100.600 \\
\hline $\begin{array}{l}\text { CRM 482 } \\
\text { obtained }\end{array}$ & 42.082 & 0.576 & 0.494 & 2.485 & 4.222 & 7.247 & 102.219 \\
\hline SD & 0.902 & 0.065 & 0.340 & 0.148 & 0.190 & 0.525 & 2.488 \\
\hline difference (\%) & 2.89 & 2.78 & 2.92 & 0.61 & 2.48 & 3.08 & 1.61 \\
\hline $\begin{array}{l}\text { BCR 60 } \\
\text { certificated }\end{array}$ & 63.800 & 2.120 & 0.340 & $40.000^{*}$ & $26.000^{*}$ & 51.200 & 313.000 \\
\hline $\begin{array}{l}\text { BCR 60 } \\
\text { obtained }\end{array}$ & 64.027 & 2.160 & 0.338 & 40.768 & 26.850 & 51.650 & 311.322 \\
\hline SD & 2.308 & 0.179 & 0.030 & 1.942 & 2.399 & 2.670 & 3.721 \\
\hline difference (\%) & 0.36 & 1.89 & -0.53 & 1.92 & 3.27 & 0.87 & -0.54 \\
\hline $\begin{array}{l}\text { LGC 6187 } \\
\text { certificated }\end{array}$ & 77.200 & 2.700 & 1.400 & 34.700 & 84.000 & - & 439.000 \\
\hline $\begin{array}{l}\text { LGC 6187 } \\
\text { obtained }\end{array}$ & 78.100 & 2.746 & 1.424 & 34.740 & 84.836 & - & 438.690 \\
\hline SD & 1.122 & 0.128 & 0.037 & 1.514 & 1.791 & 1.00 & - \\
\hline difference (\%) & 1.16 & 1.70 & 1.74 & 0.12 & & -0.07 \\
\hline
\end{tabular}

* - not certificated values; SD - standard deviation

Table 2. Physical and chemical parameters of water - temperature $\left({ }^{\circ} \mathrm{C}\right)$, $\mathrm{pH}$, electrolytic conductivity $\left(\mu \mathrm{S} \cdot \mathrm{cm}^{-1}\right)$, alkalinity $\left(\mathrm{mg} \mathrm{CaCO}{ }_{3} \cdot \mathrm{dm}^{-3}\right)$, total hardness $\left(\mathrm{mg} \mathrm{CaCO} \cdot \mathrm{dm}^{-3}\right)$, dissolved oxygen $\left(\mathrm{mg} \mathrm{O}_{2} \cdot \mathrm{dm}^{-3}\right)$ and $\mathrm{BOD}_{5}\left(\mathrm{mg} \mathrm{O}_{2} \cdot \mathrm{dm}^{-3}\right)$

\begin{tabular}{|c|c|c|c|c|c|c|c|}
\hline & Temperature & $\mathrm{pH}$ & $\begin{array}{c}\text { Electrolytic } \\
\text { conductivity }\end{array}$ & Alkalinity & $\begin{array}{c}\text { Total } \\
\text { hardness }\end{array}$ & $\begin{array}{c}\text { Dissolved } \\
\text { oxygen }^{-1}\end{array}$ & BOD $_{5}$ \\
\hline Average & 10.12 & - & 144.35 & 44.646 & 74.427 & 11.51 & 2.8 \\
\hline Min & 6.5 & 6.9 & 87 & 19.99 & 55.34 & 10.2 & 1.1 \\
\hline Max & 14.0 & 8.1 & 236 & 99.94 & 110.67 & 12.4 & 7.7 \\
\hline SD & 2.43 & - & 42.83 & 19.05 & 16.93 & 0.60 & 1.22 \\
\hline
\end{tabular}


Table 3. Concentrations of $\mathrm{Pb}, \mathrm{Hg}, \mathrm{Cd}, \mathrm{Ni}, \mathrm{Cr}, \mathrm{Cu}$ and $\mathrm{Zn}$ in water $\left(\mu \mathrm{g} \cdot \mathrm{dm}^{-3}\right)$

\begin{tabular}{|l|c|c|c|c|c|c|c|}
\hline & $\mathrm{Pb}$ & $\mathrm{Hg}$ & $\mathrm{Cd}$ & $\mathrm{Ni}$ & $\mathrm{Cr}$ & $\mathrm{Cu}$ & $\mathrm{Zn}$ \\
\hline Average & 4.99 & 0.57 & 0.79 & 1.55 & 0.90 & 2.09 & 8.43 \\
\hline Min & 0.60 & 0.20 & 0.20 & 0.10 & 0.10 & 1.00 & 0.10 \\
\hline Max & 11.10 & 1.40 & 1.90 & 5.80 & 2.10 & 4.20 & 29.60 \\
\hline SD & 2.86 & 0.31 & 0.42 & 1.36 & 0.55 & 0.86 & 6.32 \\
\hline
\end{tabular}

SD - standard deviation

Table 4. Concentrations of $\mathrm{Pb}, \mathrm{Hg}, \mathrm{Ni}, \mathrm{Cu}$ and $\mathrm{Zn}$ in bottom deposits $\left(\mathrm{mg} \cdot \mathrm{kg}^{-1}\right)$

\begin{tabular}{|l|r|r|r|r|r|}
\hline & $\mathrm{Pb}$ & $\mathrm{Hg}$ & $\mathrm{Ni}$ & $\mathrm{Cu}$ & $\mathrm{Zn}$ \\
\hline Average & 56.28 & 0.03 & 14.71 & 13.78 & 74.24 \\
\hline Min & 10.39 & 0.01 & 8.94 & 6.66 & 45.35 \\
\hline Max & 134.41 & 0.08 & 18.94 & 20.37 & 116.58 \\
\hline SD & 40.96 & 0.03 & 3.32 & 4.42 & 21.64 \\
\hline
\end{tabular}

SD - standard deviation

Among the studied metals in plants, $\mathrm{Zn}$ was found most frequently, whereas $\mathrm{Hg}$ the least (Table 5), and the differences between concentration of these metals were very high. The concentration of $\mathrm{Zn}$ in $F$. antipyretica was 1,500 times higher than the concentration of $\mathrm{Hg}$ in $F$. antipyretica. In $R$. aquatile the concentration of $\mathrm{Zn}$ was 10,300 times higher than the concentration of $\mathrm{Hg}$. The significance of difference between concentrations of metals in different plant species was also calculated (Table 5).

The noted metal content in water and plants allowed for the calculation of the bioconcentration factors (BCFs). The obtained results are shown in Fig 2 and in Table 6 . The trends, which are visible on the graph (Fig. 2), have been confirmed by the demonstration of the statistical significance of difference as shown in Table 6 (all metals except $\mathrm{Pb}$ ).

The correlation between physicochemical parameters of water, metal concentrations in water, sediment, plants and the metal concentration (Tables 7, 8, and 9), and BCFs for metals in plants (Tables 10, 11, and 12) were calculated. Only statistically significant $(\mathrm{p} \leq 0.05)$ correlations are presented in the Tables.

All other correlations should be considered as strong, $\mathrm{r}$ ranged from -1.0 to -0.5 , and from 0.5 to 1.0 .

\section{Discussion}

Kozubek et al. (2002) conducted research on the Bystrzyca Dusznicka River which is similar to and located near the Biała Lądecka.

These authors found that $\mathrm{pH}$ and conductivity of the Bystrzyca Dusznicka River were similar to those of the Biała Lądecka. They also found that $\mathrm{BOD}_{5}$ was significantly lower $\left(0.82 \mathrm{mg} \mathrm{O}_{2} \cdot \mathrm{dm}^{-3}\right)$, dissolved oxygen levels $\left(9.68 \mathrm{mg} \mathrm{O}_{2} \cdot \mathrm{dm}^{-3}\right)$ were also lower, and total hardness was higher $(118.6 \mathrm{mg}$ $\left.\mathrm{CaCO}_{3} \cdot \mathrm{dm}^{-3}\right)$.

Simić (2007) gives similar values of the physicochemical water parameters of the Rešava River and the Božička River in Serbia, where there were L. fluviatilis populations. Say et al. (1983) noted the results of various authors concerning the $\mathrm{pH}$ and electrolytic conductivity of water from the habitats of $F$. antipyretica and Ranunculus sp. ( $R$. aquatile and $R$. penicilatus). The $\mathrm{pH}$ from these sites ranged from 6.5 to 8.1 , and the electrolytic conductivity was higher than in the Biała Lądecka River - 70-615 $\mu \mathrm{S} \cdot \mathrm{cm}^{-1}$. During their research Say et al. (1983) determined the parameters of water in the places where $F$. antipyretica was found. At these places, the $\mathrm{pH}$ was 7.5 and electrolytic conductivity was $296 \mu \mathrm{S} \cdot \mathrm{cm}^{-1}$.

Metal concentrations in the water of the Biała Lądecka River differed from the concentrations described by Kozubek et al. (2002). They reported higher concentrations of $\mathrm{Pb}$ $\left(30.69 \mu \mathrm{g} \cdot \mathrm{dm}^{-3}\right), \mathrm{Hg}\left(3.1 \mu \mathrm{g} \cdot \mathrm{dm}^{-3}\right), \mathrm{Ni}\left(5.11 \mu \mathrm{g} \cdot \mathrm{dm}^{-3}\right)$, and $\mathrm{Zn}\left(28.65 \mu \mathrm{g} \cdot \mathrm{dm}^{-3}\right)$. The values they reported are several times higher than those in the Biała Lądecka River, however, the $\mathrm{Cu}$ content was comparable $\left(2.69 \mu \mathrm{g} \cdot \mathrm{dm}^{-3}\right)$, though the $\mathrm{Cd}$ content was less comparable $\left(0.3 \mu \mathrm{g} \cdot \mathrm{dm}^{-3}\right)$. In the mountain river Bystrzyca and its tributaries (also in the Sudety Mts), Senze et al. (2007) found higher amounts of $\mathrm{Cu}, \mathrm{Ni}$ and $\mathrm{Zn}$ (for $\mathrm{Cu}$ and $\mathrm{Zn}-2$ times higher), and lower $\mathrm{Cd}$ and $\mathrm{Pb}$ than we had found in the Biała Lądecka River. On habitats of $F$. antipyretica, Say et al. (1983) found similar amounts of $\mathrm{Pb}\left(4.2 \mu \mathrm{g} \cdot \mathrm{dm}^{-}\right.$ $\left.{ }^{3}\right)$, smaller amounts of $\mathrm{Cd}\left(0.4 \mu \mathrm{g} \cdot \mathrm{dm}^{-3}\right)$, higher amounts of $\mathrm{Cu}\left(4.5 \mu \mathrm{g} \cdot \mathrm{dm}^{-3}\right)$ and significantly higher amounts of $\mathrm{Zn}$ $\left(83 \mu \mathrm{g} \cdot \mathrm{dm}^{-3}\right)$. Samecka-Cymerman et al. (1999) analyzed bryophytes from mountain rivers in basaltic areas of central France. They found different levels of metals in the water: much higher of $\mathrm{Cr}\left(5.1-12.9 \mu \mathrm{g} \cdot \mathrm{dm}^{-3}\right)$, Ni $\left(6.4-29 \mu \mathrm{g} \cdot \mathrm{dm}^{-3}\right)$, and $\mathrm{Zn}\left(27-48 \mu \mathrm{g} \cdot \mathrm{dm}^{-3}\right)$, Cu which was comparable $(1-4.6 \mu \mathrm{g}$ $\left.\cdot \mathrm{dm}^{-3}\right)$, and significantly lower of Cd $\left(0.003-0.142 \mu \mathrm{g} \cdot \mathrm{dm}^{-3}\right)$ than the same metal levels in the Biała Lądecka River.

The metal concentrations found in the water of the Biała Lądecka River are similar to the concentrations found in other clean European rivers (Neal et al. 1998, Vázquez et al. 2000, Samecka-Cymerman et al. 2005, Gecheva et al. 2011).

The metal content in sediment was significantly higher than that found in the water of the Biała Lądecka River. The metal concentration in sediment to metal concentration in 
Table 5. Concentrations of $\mathrm{Pb}, \mathrm{Hg}, \mathrm{Cd}, \mathrm{Ni}, \mathrm{Cr}, \mathrm{Cu}$ and $\mathrm{Zn}$ in R.aquatile, F. antipyretica and L. fluviatilis (mg $\cdot \mathrm{kg}^{-1} \mathrm{in} \mathrm{dry}$ weight)

\begin{tabular}{|l|l|c|c|c|c|c|c|c|}
\hline & & $\mathrm{Pb}$ & $\mathrm{Hg}$ & $\mathrm{Cd}$ & $\mathrm{Ni}$ & $\mathrm{Cr}$ & $\mathrm{Cu}$ & $\mathrm{Zn}$ \\
\hline Ranunculus & Average & $77.44^{\mathrm{a}}$ & $0.068^{\mathrm{A}}$ & $2.560^{\mathrm{A}}$ & $10.25^{\mathrm{A}}$ & $5.289^{\mathrm{A}}$ & $23.46^{\mathrm{A}}$ & $701.1^{\mathrm{A}}$ \\
& Min & 8.63 & 0.027 & 0.680 & 5.59 & 2.453 & 16.86 & 148.9 \\
& $\mathrm{Max}$ & 245.65 & 0.126 & 4.460 & 18.61 & 9.385 & 34.11 & 2093.4 \\
& $\mathrm{SD}$ & 74.12 & 0.024 & 1.093 & 4.22 & 2.381 & 5.59 & 604.3 \\
\hline Fontinalis & Average & $35.66^{\mathrm{a}}$ & $0.104^{\mathrm{B}}$ & $0.689^{\mathrm{B}}$ & $11.95^{\mathrm{A}}$ & $6.446^{\mathrm{A}}$ & $23.76^{\mathrm{A}}$ & $160.3^{\mathrm{B}}$ \\
antipyretica & Min & 9.10 & 0.045 & 0.243 & 6.78 & 2.077 & 9.34 & 71.8 \\
& Max & 76.95 & 0.149 & 1.146 & 17.68 & 10.042 & 41.90 & 257.4 \\
& $\mathrm{SD}$ & 20.68 & 0.035 & 0.283 & 3.89 & 2.319 & 12.23 & 74.8 \\
\hline Lemanea & Average & $25.07^{\mathrm{b}}$ & $0.017^{\mathrm{C}}$ & $0.289^{\mathrm{B}}$ & $4.98^{\mathrm{B}}$ & $1.735^{\mathrm{B}}$ & $11.29^{\mathrm{B}}$ & $113.6^{\mathrm{B}}$ \\
fluviatilis & Min & 8.99 & 0.010 & 0.190 & 2.91 & 0.830 & 6.67 & 79.7 \\
& Max & 51.20 & 0.025 & 0.428 & 8.20 & 2.732 & 15.94 & 145.4 \\
& $\mathrm{SD}$ & 12.43 & 0.005 & 0.085 & 1.72 & 0.531 & 2.64 & 25.0 \\
\hline
\end{tabular}

different letters indicate statistically significant differences, $a b-p \leq 0.05, A B-p \leq 0.01 ; S D-$ standard deviation

Table 6. Bioconcentration factors (BCF) for $\mathrm{Pb}, \mathrm{Hg}, \mathrm{Cd}, \mathrm{Ni}, \mathrm{Cr}, \mathrm{Cu}$ and $\mathrm{Zn}$ in R.aquatile, F. antipyretica and L. fluviatilis

\begin{tabular}{|l|l|r|r|r|r|r|r|r|}
\hline & & $\mathrm{Pb}$ & $\mathrm{Hg}$ & $\mathrm{Cd}$ & $\mathrm{Ni}$ & $\mathrm{Cr}$ & $\mathrm{Cu}$ & $\mathrm{Zn}$ \\
\hline & Average & $17851^{\mathrm{a}}$ & $149^{\mathrm{A}}$ & $4496^{\mathrm{A}}$ & $9084^{\mathrm{A}}$ & $55^{\mathrm{A}}$ & $13224^{\mathrm{a}}$ & $9^{\mathrm{A}}$ \\
Ranunculus & Min & 1952 & 39 & 755 & 3004 & 1950 & 4904 & 11134 \\
aquatile & Max & 58197 & 319 & 12038 & 37538 & 11731 & 34108 & 309482 \\
& $\mathrm{SD}$ & 17483 & 92 & 3746 & 8461 & 3688 & 6624 & 91435 \\
\hline & Average & $8047^{\mathrm{a}}$ & $226^{\mathrm{A}}$ & $920^{\mathrm{B}}$ & $26404^{\mathrm{Ba}}$ & $12258^{\mathrm{B}}$ & $13789^{\mathrm{a}}$ & $33978^{\mathrm{b}}$ \\
Fontinalis & Min & 3838 & 65 & 280 & 3601 & 4096 & 4092 & 9195 \\
antipyretica & Max & 21066 & 410 & 1432 & 67776 & 20766 & 32404 & 95321 \\
& $\mathrm{SD}$ & 5218 & 123 & 456 & 23667 & 5774 & 10144 & 29803 \\
\hline & Average & $7036^{\mathrm{a}}$ & $29^{\mathrm{B}}$ & $396^{\mathrm{B}}$ & $12046^{\mathrm{ABb}}$ & $3029^{\mathrm{A}}$ & $5857^{\mathrm{b}}$ & $24111^{\mathrm{b}}$ \\
Lemanea & Min & 2362 & 10 & 128 & 1020 & 838 & 2996 & 11892 \\
fluviatilis & Max & 13371 & 43 & 681 & 33234 & 4914 & 8951 & 53007 \\
& $\mathrm{SD}$ & 4187 & 13 & 198 & 11580 & 1616 & 2000 & 14809 \\
\hline
\end{tabular}

different letters indicate statistically significant differences, $a b-p \leq 0.05, A B-p \leq 0.01 ; S D$ - standard deviation

water ratio was almost 10,000 for $\mathrm{Pb}, \mathrm{Ni}$ and $\mathrm{Zn}$. For $\mathrm{Cu}$, this ratio was 6600 . For $\mathrm{Hg}$, the ratio was quite different; only 53.

In terms of metal content, the bottom sediment of the Biała Lądecka River (Table 4) belongs to class I classification, only the $\mathrm{Pb}$ content was typical of the class II classification of bottom sediment (Bojakowska 2001). These values do not differ from the values reported by other researchers for other rivers (Say et al. 1983, Ciszewski 2001, Ibragimow et al. 2013, Pokorny et al. 2013, Jabłońska-Czapla et al. 2014).

The metal content in the water and sediment of the Biała Lądecka River was characterized by high volatility. The volatility can be expressed as a variability coefficient calculated from the formula: Standard Deviation/Average - 100\%. For metals in water, the variability coefficient ranged from $41 \%$ (for $\mathrm{Cu}$ ) to $88 \%$ (for $\mathrm{Ni}$ ). The metal content of the sediment had a lower variability coefficient for $\mathrm{Ni}, \mathrm{Cu}$, and $\mathrm{Zn}(23 \%, 32 \%$, and $29 \%$, respectively), and a higher variability coefficient for $\mathrm{Pb}$ and $\mathrm{Hg}$ ( $73 \%$ and $100 \%$, respectively).

The variability coefficient for the metal content in plants was lower than the variability coefficient for the metal content in water and sediment. However, the variation coefficient differed depending on the plant species. The highest was for $R$. aquatile (from $24 \%$ to $96 \%$ for $\mathrm{Cu}$ and $\mathrm{Pb}$, respectively) and the lowest was for L. fluviatilis (from $22 \%$ to $50 \%$ for $\mathrm{Zn}$ and $\mathrm{Pb}$, respectively).

The metal concentrations in all the species of plants from the Biała Lądecka River study, can be arranged as follows: $\mathrm{Hg}<\mathrm{Cd}<\mathrm{Cr}<\mathrm{Ni}<\mathrm{Cu}<\mathrm{Pb}<\mathrm{Zn}$, and arrangement is the same for the water. Among the studied plants, the lowest metal concentrations were found in L. fluviatilis. Of all species of plants, $F$. antipyretica contained the highest amount of $\mathrm{Hg}$, $\mathrm{Ni}, \mathrm{Cr}, \mathrm{Cu}$, and $R$. aquatile contained the highest amout of $\mathrm{Pb}, \mathrm{Cd}$ and $\mathrm{Zn}$. We found statistically significant differences $(\mathrm{Pb}-\mathrm{p} \leq 0.05$, all other $-\mathrm{p} \leq 0.01)$ between the content of each metal in L. fluviatilis, and in $R$. aquatile.

The contents of all metals in $F$. antipyretica were higher than the metals content in L. fluviatilis. The differences for $\mathrm{Hg}, \mathrm{Ni}, \mathrm{Cr}$, and $\mathrm{Cu}$ were statistically significant $(\mathrm{p} \leq 0.01)$.

As indicated by available literature, the metal levels in plants from the present Biała Lądecka River study were similar to the results of other authors. In R. aquatile, Martinez 

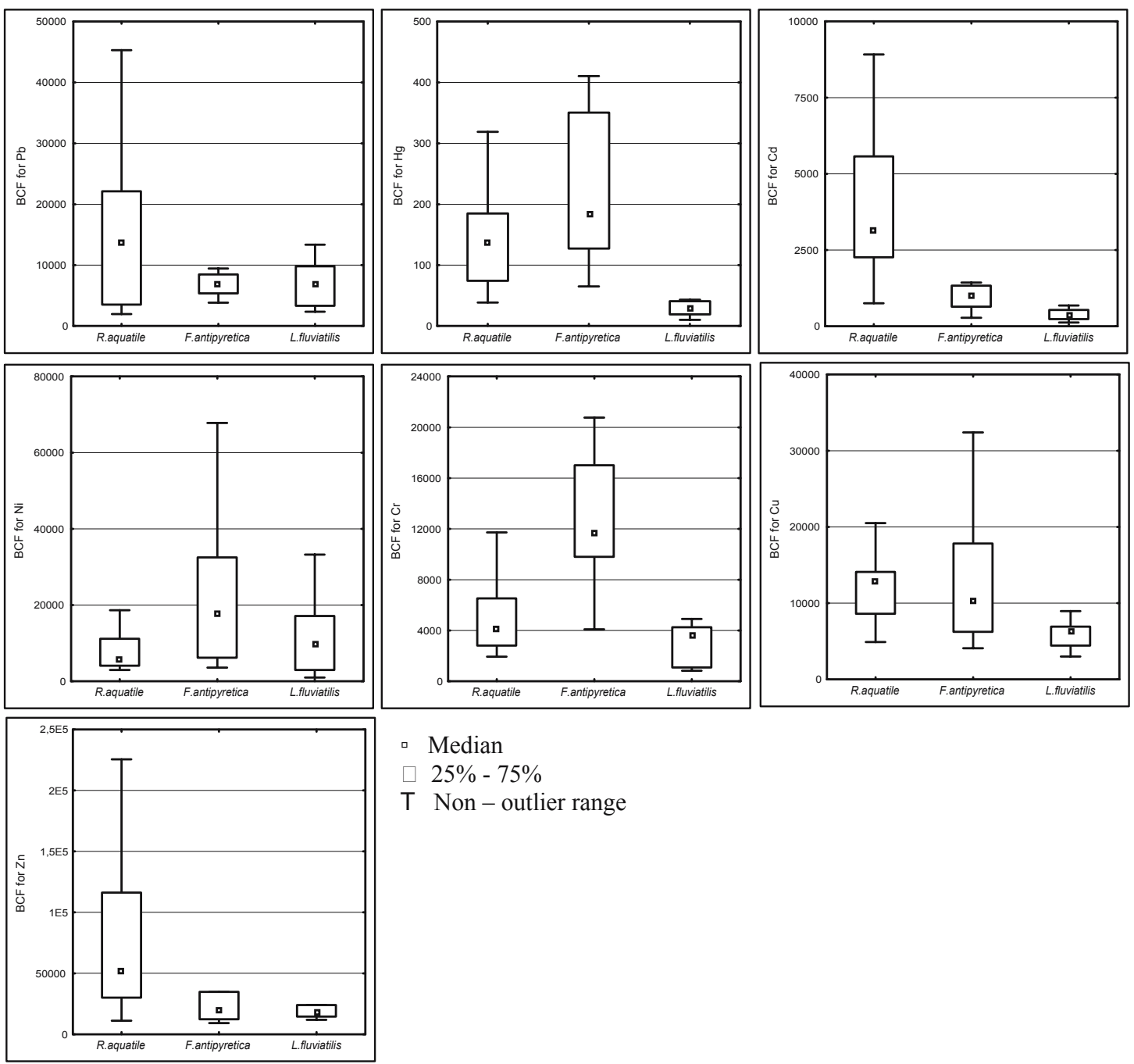
- Median
$25 \%-75 \%$
$\mathrm{T}$ Non - outlier range

Fig. 1. Median and range of BCF values for metals in R. aquatile, F. antipyretica and L. fluviatilis

Table 7. Statistically significant $(p \leq 0.05)$ correlations between physicochemical parameters of water and content of the investigated metals in water, sediment and the metal concentration in $R$. aquatile

\begin{tabular}{|c|c|c|c|}
\hline $\begin{array}{l}\text { Relations between } \\
\qquad(x \text { and } y)\end{array}$ & Regression equation & $\begin{array}{l}\text { Correlation coefficient } \\
\text { (r) }\end{array}$ & $\begin{array}{c}\text { Significant level } \\
(p)\end{array}$ \\
\hline Cond : Zn in R. aq. & $y=-268.6133+6.7003 x$ & 0.5084 & 0.0312 \\
\hline Cond : Cd in R. aq. & $y=-1539.251+100.213 x$ & 0.6955 & 0.0009 \\
\hline Alk : Ni in R. aq. & $y=5.4408+0.1053 x$ & 0.5198 & 0.0226 \\
\hline Th : Zn in R. aq. & $y=-716.4021+18.7345 x$ & 0.5313 & 0.0233 \\
\hline $\mathrm{BOD}_{5}: \mathrm{Pb}$ in R. aq. & $y=-26.6462+36.4196 x$ & 0.6582 & 0.0022 \\
\hline $\mathrm{Pb}$ in water: $\mathrm{Pb}$ in $\mathrm{R} . \mathrm{aq}$. & $y=0.7298+14574.4153 x$ & 0.5512 & 0.0144 \\
\hline Zn in water: Cd in R. aq. & $y=1.2915+231.4913 x$ & 0.8333 & 0.0053 \\
\hline Ni in water : Ni in R. aq. & $y=6.9403+1855.1593 x$ & 0.6035 & 0.0062 \\
\hline $\mathrm{Cr}$ in water : $\mathrm{Zn}$ in $\mathrm{R}$. aq. & $y=1209.9989-5.1465 E 5 x$ & -0.4948 & 0.0369 \\
\hline $\mathrm{Pb}$ in sed. : $\mathrm{Pb}$ in $\mathrm{R}$. aq. & $y=-21.8663+1.5595 x$ & 0.8688 & 0.00000 \\
\hline Zn in sed. : Zn in R. aq. & $y=1859.2892-14.8605 x$ & -0.5531 & 0.0173 \\
\hline Cu in sed. : Zn in R. aq. & $y=2031.2182-92.7053 x$ & -0.7159 & 0.0008 \\
\hline $\mathrm{Ni}$ in sed. : Zn in R. aq. & $y=2251.2317-102.9232 x$ & -05887 & 0.0102 \\
\hline Hg in sed. : Zn in R. aq. & $y=1163.0296-11629.7886 x$ & -0.5988 & 0.0086 \\
\hline
\end{tabular}

R. aq. - Ranunculus aquatile; Cond - electrolytic conductivity; Alk - alkalinity; Th - total hardness; sed. - sediment 
Table 8. Statistically significant $(p \leq 0.05)$ correlations between physicochemical parameters of water and content of the investigated metals in water, sediment and the metal concentration in F. antipyretica

\begin{tabular}{|c|c|c|c|}
\hline $\begin{array}{l}\text { Relations between } \\
\qquad(x \text { and } y)\end{array}$ & Regression equation & $\begin{array}{l}\text { Correlation } \\
\text { coefficient }(r)\end{array}$ & $\begin{array}{c}\text { Significant level } \\
(p)\end{array}$ \\
\hline Alk : Cr in Font. & $y=14.0267-0.2254 x$ & -0.9581 & 0.00005 \\
\hline Th : Cu in Font. & $y=-45.5121+1.0276 x$ & 0.7118 & 0.0315 \\
\hline $\mathrm{O}_{2}:$ Cu in Font. & $y=219.207-16.8977 x$ & -0.6875 & 0.0407 \\
\hline $\mathrm{Pb}$ in water : $\mathrm{Pb}$ in Font. & $y=8.4316+5117.0033 x$ & 0.7504 & 0.0198 \\
\hline $\mathrm{Pb}$ in water : $\mathrm{Ni}$ in Font. & $y=6.6759+991.1837 x$ & 0.7730 & 0.0146 \\
\hline $\mathrm{Zn}$ in water : $\mathrm{Pb}$ in Font. & $y=73.4723-6065.2731 x$ & -0.7263 & 0.0267 \\
\hline Zn in water : Ni in Font. & $y=18.5588-1060.0333 x$ & -0.6751 & 0.0460 \\
\hline $\mathrm{Ni}$ in water : $\mathrm{Pb}$ in Font. & $y=20.4559+13036.7567 x$ & 0.8171 & 0.0072 \\
\hline $\mathrm{Hg}$ in water : $\mathrm{Cr}$ in Font. & $y=3.7307+4610.7845 x$ & 0.6847 & 0.0419 \\
\hline $\mathrm{Pb}$ in sed. : $\mathrm{Pb}$ in Font. & $y=14.8068+0.3328 x$ & 0.8211 & 0.0067 \\
\hline $\mathrm{Pb}$ in sed. : $\mathrm{Cu}$ in Font. & $y=12.0882+0.1862 x$ & 0.7767 & 0.0138 \\
\hline $\mathrm{Pb}$ in sed. : $\mathrm{Ni}$ in Font. & $y=7.6636+0.0684 x$ & 0.8976 & 0.0010 \\
\hline $\mathrm{Zn}$ in sed. : $\mathrm{Pb}$ in Font. & $y=-11.9592+0.6015 x$ & 0.7434 & 0.0217 \\
\hline $\mathrm{Hg}$ in sed. : $\mathrm{Pb}$ in Font. & $y=15.5155+479.7585 x$ & 0.7457 & 0.0211 \\
\hline
\end{tabular}

Font - Fontinalis antipyretica; Alk - alkalinity; Th - total hardness; $\mathrm{O}_{2}$ - dissolved oxygen; sed. - sediment

Table 9. Statistically significant $(p \leq 0.05)$ correlations between physicochemical parameters of water and content of the investigated metals in water, sediment and the metal concentration in L. fluviatilis

\begin{tabular}{|c|c|c|c|}
\hline $\begin{array}{l}\text { Relations between } \\
\qquad(x \text { and } y)\end{array}$ & Regression equation & $\begin{array}{l}\text { Correlation coefficient } \\
\text { (r) }\end{array}$ & $\begin{array}{c}\text { Significant level } \\
(p)\end{array}$ \\
\hline Cond : $\mathrm{Hg}$ in Lem. & $y=-0.0029+0.0002 x$ & 0.8831 & 0.0016 \\
\hline Th : Ni in Lem. & $y=-7.4287+0.1938 x$ & 0.6706 & 0.0481 \\
\hline Th : Cd in Lem. & $y=-0.4263+0.0112 x$ & 0.7812 & 0.0129 \\
\hline Th: Cr in Lem. & $y=-2.6022+0.0677 x$ & 0.7597 & 0.0175 \\
\hline Zn in water : $\mathrm{Cr}$ in Lem. & $y=2.8998+207.1143 x$ & -0.7709 & 0.0150 \\
\hline $\mathrm{Pb}$ in sed. : $\mathrm{Pb}$ in Lem. & $y=15.0003+0.1627 x$ & 0.6733 & 0.0468 \\
\hline Cu in sed. : Hg in Lem. & $y=0.0258-0.0006 x$ & -0.6933 & 0.0384 \\
\hline $\mathrm{Ni}$ in sed. : Hg in Lem. & $y=0.0304-0.0009 x$ & -0.7854 & 0.0121 \\
\hline
\end{tabular}

Lem. - Lemanea fluvitans; sed. - sediment; Cond - electrolytic conductivity; Th - total hardness;

Table 10. Statistically significant $(p \leq 0.05)$ correlations between physicochemical parameters of water and content of the investigated metals in water, sediment and the BCF for metal in $R$. aquatile

\begin{tabular}{|c|c|c|c|}
\hline $\begin{array}{l}\text { Relations between } \\
\qquad(\mathrm{x} \text { and } \mathrm{y})\end{array}$ & Regression equation & $\begin{array}{l}\text { Correlation coefficient } \\
\text { (r) }\end{array}$ & $\begin{array}{c}\text { Significant level } \\
(p)\end{array}$ \\
\hline $\mathrm{Zn}$ in water : BCF $\mathrm{Pb}$ in $\mathrm{R}$. aq. & $y=3456.1036+1.6003 E 6 x$ & 0.62 & 0.004 \\
\hline $\mathrm{Pb}$ in water : $\mathrm{BCF} \mathrm{Cd}$ in $\mathrm{R}$. aq. & $y=1137.7484-1.186 E 6 x$ & -0.75 & 0.020 \\
\hline Zn in water : BCF Cd in R. aq. & $y=936.8764+6.4978 E 5 x$ & 0.68 & 0.043 \\
\hline Cd in R. aq. : BCF Ni in R. aq. & $y=18054.0579-3598.0412 x$ & -0.67 & 0.047 \\
\hline Cond : BCF Cu in R. aq. & $y=1539.251+100.213 x$ & 0.70 & 0.001 \\
\hline Alk : BCF Cu in R. aq. & $y=2733.5963+229.571 x$ & 0.72 & 0.001 \\
\hline Th : BCF Cu in R. aq. & $y=-7840.0059+274.0981 x$ & 0.72 & 0.001 \\
\hline $\mathrm{Ni}$ in water : BCF Cu in R. aq. & $y=9001.8029+2.3663 E 6 x$ & 0.49 & 0.033 \\
\hline $\mathrm{Cr}$ in water : BCF Cu in R. aq. & $y=18950.3289-5.7569 E 6 x$ & -0.49 & 0.033 \\
\hline $\mathrm{Hg}$ in sed. : BCF Cu in R. aq. & $y=17272.3509-1.0657 E 5 x$ & -0.50 & 0.029 \\
\hline
\end{tabular}

R. aq. - Ranunculus aquatile; Cond - electrolytic conductivity; Alk - alkalinity; Th - total hardness; sed. - sediment 
Table 11. Statistically significant $(p \leq 0.05)$ correlations between physicochemical parameters of water and content of the investigated metals in water, sediment, and plant and the BCF for metal in F. antipyretica

\begin{tabular}{|l|l|c|c|}
\hline \multicolumn{1}{|c|}{$\begin{array}{c}\text { Relations between } \\
(\mathrm{x} \text { and } \mathrm{y})\end{array}$} & \multicolumn{1}{|c|}{ Regression equation } & $\begin{array}{c}\text { Correlation coefficient } \\
(\mathrm{r})\end{array}$ & $\begin{array}{c}\text { Significant level } \\
(\mathrm{p})\end{array}$ \\
\hline $\mathrm{Hg}$ in water : BCF Pb in Font. & $\mathrm{y}=814.1135+1.2283 \mathrm{E} 7 \mathrm{x}$ & 0.81 & 0.008 \\
\hline $\mathrm{Th}: \mathrm{BCF} \mathrm{Hg}$ in Font. & $\mathrm{y}=-468.5711+10.2205 \mathrm{x}$ & 0.68 & 0.030 \\
\hline $\mathrm{O}_{2}$ : BCF Hg in Font. & $\mathrm{y}=2602.9746-205.9489 \mathrm{x}$ & -0.80 & 0.006 \\
\hline $\mathrm{Hg}$ in sed. : BCF Ni in Font. & $\mathrm{y}=47120.207-4.9324 \mathrm{E} 5 \mathrm{x}$ & -0.67 & 0.048 \\
\hline $\mathrm{Th}:$ BCF Cu in Font. & $\mathrm{y}=-52677.9782+985.9972 \mathrm{x}$ & 0.82 & 0.006 \\
\hline $\mathrm{O}_{2}$ : BCF Cu in Font. & $\mathrm{y}=2.1071 \mathrm{E} 5-17024.9992 \mathrm{x}$ & -0.84 & 0.005 \\
\hline $\mathrm{Pb}$ in sed. : BCF Zn in Font. & $\mathrm{y}=3880.3069+480.2388 \mathrm{x}$ & 0.82 & 0.007 \\
\hline $\mathrm{Zn}$ in sed. : BCF Zn in Font. & $\mathrm{y}=-31942.6097+832.6085 \mathrm{x}$ & 0.71 & 0.031 \\
\hline
\end{tabular}

Font - Fontinalis antipyretica; Th - total hardness; $\mathrm{O}_{2}$ - dissolved oxygen; sed. - sediment

Table 12. Statistically significant $(p \leq 0.05)$ correlations between physicochemical parameters of water and content of the investigated metals in water, sediment, and plant and the BCF for metal in L. fluviatilis

\begin{tabular}{|l|l|c|c|}
\hline \multicolumn{1}{|c|}{$\begin{array}{c}\text { Relations between } \\
(x \text { and } y)\end{array}$} & \multicolumn{1}{|c|}{ Regression equation } & $\begin{array}{c}\text { Correlation coefficient } \\
(r)\end{array}$ & $\begin{array}{c}\text { Significant level } \\
(p)\end{array}$ \\
\hline Cd in water : BCF Pb in Lem. & $y=13153.7168-6.7147 \mathrm{E} 6 \mathrm{x}$ & -0.80 & 0.009 \\
\hline Alk : BCF Cd in Lem. & $y=1010.384-18.8766 x$ & -0.71 & 0.033 \\
\hline Cu in water : BCF Cd in Lem. & $y=697.097-1.4022 \mathrm{E} 5 \mathrm{x}$ & -0.68 & 0.045 \\
\hline $\mathrm{Hg}$ in sed. : BCF Ni in Lem. & $\mathrm{y}=22830.9852-2.5959 \mathrm{E} 5 \mathrm{x}$ & -0.73 & 0.025 \\
\hline $\mathrm{BOD}_{5}$ : BCF Cu in Lem. & $\mathrm{y}=12016.3846-2399.7702 \mathrm{x}$ & -0.77 & 0.015 \\
\hline Cd in water : BCF Cu in Lem. & $\mathrm{y}=8658.223-3.0745 \mathrm{E} 6 \mathrm{x}$ & -0.77 & 0.015 \\
\hline Pb in sed. : BCF Zn in Lem. & $\mathrm{y}=10519.1522+219.5411 \mathrm{x}$ & 0.76 & 0.017 \\
\hline Zn in sed. : BCF Zn in Lem. & $\mathrm{y}=-6254.2987+388.7518 \mathrm{x}$ & 0.71 & 0.034 \\
\hline
\end{tabular}

Lem. - Lemanea fluvitans; Alk - alkalinity; sed. - sediment

et al. (2011) found higher amounts of $\mathrm{Hg}$ and $\mathrm{Cu}$ (respectively, $1.045 \mathrm{mg} \cdot \mathrm{kg}^{-1}$ and $\left.53.15 \mathrm{mg} \cdot \mathrm{kg}^{-1}\right)$ but smaller amounts of $\mathrm{Cd}$ and $\mathrm{Zn}$ (respectively, $0.555 \mathrm{mg} \cdot \mathrm{kg}^{-1}$ and $61.25 \mathrm{mg} \cdot \mathrm{kg}^{-1}$ ).

Samecka-Cymerman et al. (1996) found in R. aquatile (from contaminated river) higher amounts of $\mathrm{Hg}$ and $\mathrm{Ni}$ $\left(0.16 \mathrm{mg} \cdot \mathrm{kg}^{-1}\right.$ and $\left.9.5 \mathrm{mg} \cdot \mathrm{kg}^{-1}\right)$ but smaller $\mathrm{Pb}, \mathrm{Cd}, \mathrm{Cr}$, $\mathrm{Cu}$ and $\mathrm{Zn}\left(1.6 \mathrm{mg} \cdot \mathrm{kg}^{-1}, 0.63 \mathrm{mg} \cdot \mathrm{kg}^{-1}, 2.4 \mathrm{mg} \cdot \mathrm{kg}^{-1}, 7.1 \mathrm{mg}\right.$ $\cdot \mathrm{kg}^{-1}$ and $\left.101 \mathrm{mg} \cdot \mathrm{kg}^{-1}\right)$.

There is much more information in the literature concerning $F$. antipyretica. In our study, the indicated concentrations of $\mathrm{Pb}, \mathrm{Cd}, \mathrm{Ni}, \mathrm{Cr}$, and $\mathrm{Cu}$ in this moss were in the range reported by the following authors (Say et al. 1983, Vazquez et al. 2004, Gapeeva et al. 2010, Gecheva et al. 2011, Martinez et al. 2011). However, in the case of $\mathrm{Hg}$ and $\mathrm{Zn}$, the maximum values given by the authors are much higher than those obtained in our study. In $F$. antipyretica, Vazquez et al. (2004) even found $0.76 \mathrm{mg} \cdot \mathrm{kg}^{-1}$ (5 times more than the maximum value found in our study) and $1107 \mathrm{mg} \cdot \mathrm{kg}^{-1} \mathrm{Zn}$ (4 times more). In $F$. antipyretica, Say et al. (1983) found $2825 \mathrm{mg} \cdot \mathrm{kg}^{-1} \mathrm{Zn}$ (11 times more).

Correlation coefficients between the analyzed factors (physical and chemical parameters of water, metal concentration in water, sediment, and plants) were calculated. Among the statistically proven correlations, some can be distinguished. What would seem to be the obvious relationship of the metal content in water and the content of the same metal in plant, was actually only statistically confirmed in three cases. The three cases were: 1) $\mathrm{Pb}$ in water and $\mathrm{Pb}$ in $R$. aquatile, and 2) $\mathrm{Pb}$ in water vs. $\mathrm{Pb}$ and $F$. antipyretica., and 3$) \mathrm{Ni}$ in water and $\mathrm{Ni}$ in $R$. aquatile. All these correlations are positive and strong. Statistically significant correlations between a specific metal content in sediment and that specific metal content in plant were equally rare. The correlations were statistically confirmed only for $\mathrm{Pb}$ in sediment and $\mathrm{Pb}$ in all of plant species, and the correlations were statistically confirmed for $\mathrm{Zn}$ in sediment and $\mathrm{Zn}$ in $R$. aquatile. Interestingly, with an increase of $\mathrm{Zn}$ content in sediment, there was a decrease in the concentration of $\mathrm{Zn}$ in $R$. aquatile $(\mathrm{r}=-0.55)$. Samecka-Cymerman et al. (1999) have confirmed other correlations: $\mathrm{Cu}$ in water and $\mathrm{Ni}$ in bryophytes, $\mathrm{Cr}$ in water and $\mathrm{Pb}$ in bryophytes, $\mathrm{Pb}$ in water and $\mathrm{Cd}$ in bryophytes. But their research was carried out in different water conditions, where, above all, there was a low $\mathrm{pH}$ (5.7-6.3).

Say et al. (1983) demonstrated a correlation between $\mathrm{Cu}$ and $\mathrm{Zn}$ in water and in F. antipyretica. They also showed a correlation between the contents of $\mathrm{Cd}, \mathrm{Pb}, \mathrm{Cu}$, and $\mathrm{Zn}$ in sediment and in F. antipyretica.

The occurrence of a positive correlation between the content of the metal in water and its concentration in plant may indicate that the metal is absorbed by green part of plant, which is washed by water. The lack of such correlation does not necessarily imply a different way of metal absorption. It 
may be due to the fact that metal is present in water in less bioavailable forms. Positive correlations between the metal content in sediment and metal concentrations in plant could indicate metal absorption by the roots or rhizoids.

Bioconcentration factors vary significantly depending on the metal and the plant species. The calculated BCFs for metals, arranged in ascending order, are as follows:

$$
\begin{array}{ll}
\text { Ranunculus aquatile } & \mathrm{Hg}<\mathrm{Cd}<\mathrm{Cr}<\mathrm{Ni}<\mathrm{Cu}<\mathrm{Pb}<\mathrm{Zn} \\
\text { Fontinalis antipyretica } & \mathrm{Hg}<\mathrm{Cd}<\mathrm{Pb}<\mathrm{Cr}<\mathrm{Cu}<\mathrm{Ni}<\mathrm{Zn} \\
\text { Lemanea fluviatilis } & \mathrm{Hg}<\mathrm{Cd}<\mathrm{Cr}<\mathrm{Cu}<\mathrm{Pb}<\mathrm{Ni}<\mathrm{Zn}
\end{array}
$$

Among the analyzed metals, plants accumulated the highest amount of $\mathrm{Zn}$, and the least of $\mathrm{Cd}$ and $\mathrm{Hg}$. For nickel, the lowest BCF was calculated in R. aquatile, for all other metals the lowest BCF was calculated in L. fluviatilis.

In conclusion, we can say that the lowest bioaccumulation of metals was characterized by L. fluviatilis, and the highest by $F$. antipyretica.

Physicochemical parameters may have statistically significant influence $(\mathrm{p} \leq 0.05)$ on the BCFs for metals in plants. The following statistically significant relationships were confirmed: $\mathrm{BCF}$ for $\mathrm{Cu}$ in $R$. aquatile was correlated with the alkalinity, electrolitical conductivity, and total hardness; $\mathrm{BCF}$ for $\mathrm{Cu}$ in $\mathrm{F}$. antipyretica was correlated with total hardness and dissolved oxygen; and $\mathrm{BCF}$ for $\mathrm{Cu}$ in L. fluviatilis was correlated with $\mathrm{BOD}_{5}$. The $\mathrm{BCF}$ for $\mathrm{Hg}$ in F. antipyretica was correlated with total hardness and dissolved oxygen. The BCF for $\mathrm{Cd}$ in L. fluviatilis was correlated with alkalinity.

We managed to see some significant trends. The bioconcentration factor for $\mathrm{Zn}$ in $F$. antipyretica and L. fluviatilis was positively $(\mathrm{r}>0.7)$ correlated with the contents of $\mathrm{Pb}$ and $\mathrm{Zn}$ in river sediments. The bioconcentration factor for $\mathrm{Ni}$ was inversely proportional to concentrations of $\mathrm{Hg}$ in the sediment, for F. antipyretica, and L. fluviatilis. Whereas, in the case of $R$. aquatile, $\mathrm{Hg}$ in sediment correlated (also negatively) with $\mathrm{BCF}$ for $\mathrm{Cu}$.

\section{Conclusions}

1. The lowest concentrations of $\mathrm{Hg}$ and the highest concentrations of $\mathrm{Zn}$ were determined in the environmental elements of the Biała Ladecka River.

2. In ascending order, the metal concentrations were: water $<$ sediments $<$ plants.

3. The concentrations of metals in the water and in the plants can be arranged as follows: $\mathrm{Hg}<\mathrm{Cd}<\mathrm{Cr}<\mathrm{Ni}<\mathrm{Cu}<\mathrm{Pb}$ $<$ Zn.

4. Out of three plants species, the lowest concentrations of all metals were determined in L. fluviatilis.

5. In all plants species, the lowest BCFs were calculated for $\mathrm{Hg}$, and the highest for $\mathrm{Zn}$.

\section{Acknowledgments}

We wish to thank Dr. Pavel Kučera from the Department of Botany, Masaryk University Brno, the Czech Republic, and Dr. Petr Marvan from the Academy of Science of the Czech Republic, Institute of Botany Brno, for their help in the determination of Lemanea fluviatilis (L.) C.Ag.

\section{References}

Atherton, I., Bosanquet, S. \& Lawley, M. (2010). Mosses and Liverworts of Britain and Ireland: a field guide, British Bryological Society. Latimer Trend \& Co. Ltd., Plymounth, UK 2010.

Bojakowska, I. (2001). Criteria for assessing pollution of water sediment, Przeglad Geologiczny, 49, pp. 213-218. (in Polish)

Bory de Saint-Vincent, J.B. (1808). Mémoire sur le genre Lemanea de la famille des Conferves, A paper on the genus Lemanea of the family Conferva, 12, pp. 177-190. (in French)

Ciszewski, D. (2001). Flood-related changes in heavy metal concentrations within sediments of the Biała Przemsza River, Geomorphology, 40, pp. 205-218.

Cook, C.D.K. (1963). Studies in Ranunculus subgenus Batarchium (D.C) A. Gray. II. General morphological consideration in the taxonomy of the subgenus, Watsonia, 5, pp. 294-303.

Dahlgren, G. (1991). Karyological investigations in Ranunculus subg. Batrachium (Ranunculaceae) on the Aegean Islands, Plant Systematics and Evolution, 177, pp. 193-211.

Gapeeva, M. V., Dolotov, A. V. \& Chemeris, E. V. (2010). Prospects of using mosses (Fontinalis antipyretica Hedw. and Pylaisia polyantha (Hedw.) Bruch et al.) as indicators of environmental contamination with heavy metals, Russian Journal of Ecology, 41, pp. 28-31.

Gecheva, G., Yurukova, L. \& Ganeva, A. (2011). Assessment of pollution with aquatic bryophytes in Maritsa River (Bulgaria), Bulletin of Environmental Contamination and Toxicology, 87, pp. 480-485.

Ibragimow, A., Walna, B. \& Siepak, M. (2013). Physico-chemical parameters determining the variability of actually and potentially available fractions of heavy metals in fluvial sediments of the Middle Odra River, Archives of Environmental Protection, 39, pp. 3-16.

Jabłońska-Czapla, M., Szopa, S. \& Rosik-Dulewska, C. (2014). Impact of mining dump on the accumulation and mobility of metals in the Bytomka River Sediments, Archives of Environmental Protection, 40, pp. 3-19. Kabata-Pendias, A. \& Pendias, H. (1993). Biogeochemistry of trace elements. Wydawnictwo Naukowe PWN, Warszawa 1993. (in Polish)

Kabata-Pendias, A. \& Pendias, H. (1993). Biogeochemistry of trace elements. Wydawnictwo Naukowe PWN, Warszawa 1993. (in Polish)

Kozubek, M. \& Marek, J. (2002). Heavy metals in Bystrzyca Dusznicka River and its tributaries, Zeszyty Naukowe AR we Wrocławiu, 447, pp. 89-99. (in Polish)

Kučera, P. \& Marvan, P. (2004). Taxonomy and distribution of Lemanea and Paralemanea (Lemaneaceae, Rhodophyta) in the Czech Republic, Preslia, Praha, 76, pp. 163-174.

Martinez, E.A. \& Shu-Nyamboli, C. (2011). Determination of selected heavy metal concentrations and distribution in a southwestern stream using macrophytes, Ecotoxicology and Environmental Safety, 74, pp. 1504-1511.

Neal, C., Robson, A.J., Wass, P., Wade, A.J., Ryland, G.P., Leach, D.V. \& Leeks, G.J.L. (1998). Major, minor, trace element and suspended sediment variations in the River Derwent, The Science of the Total Environment, 210-211, pp. 163-172.

Pokorny, P., Senze, M., Dobicki, W., Kowalska-Góralska, M. \& Polechoński, R. (2013). Geochemical assessment of Western Pomerania watercourses, Przemyst Chemiczny, 92, pp. 1768-1771. (in Polish)

Samecka-Cymerman, A. \& Kempers, A.J. (1996). Bioaccumulation of heavy metals by aquatic macrophytes around Wrocław, Poland, Ecotoxicology and Environmental Safety, 35, pp. 242-247.

Samecka-Cymerman, A. \& Kempers, A.J. (1999). Background concentrations of heavy metals in aquatic bryophytes used 
for biomonitoring in basaltic areas (a case study from central France), Environmental Geology, 39, pp. 117-122.

Samecka-Cymerman, A., Kolon, K. \& Kempers, A.J. (2005). A comparison of native and transplanted Fontinalis antipyretica Hedw. as biomonitors of water polluted with heavy metals, Science of the Total Environment, 341, pp. 97-107.

Say, P.J. \& Whitton, B.A. (1983). Accumulation of heavy metals by aquatic mosses. 1: Fontinalis antipyretica Hedw, Hydrobiologia, 100, pp. 245-260.

Senze, M., Kowalska-Góralska, M. \& Pokorny, P. (2009). Metals in chosen aquatic plants in a lowland dam reservoir, Journal of Elementology, 14, pp. 147-156.

Senze, M., Pokorny, P., Polechoński, R., Dobicki, W., KowalskaGóralska, M. \& Bednarska, M. (2007). Heavy metals in hydromacrophytes of the Bystrzyca River and its tributaries above the dammed reservoir of Lubachów, Chemistry for Agriculture, 8, pp. 227-233.

Siemińska, J. (2006). Red list of the algae in Poland, in: Red list of plants and fungi in Poland, Mirek, Z., Zarzycki, Z., Wojewoda, W. \& Szeląg, Z., (Eds.). Szafer Institute of Botany, Polish Academy of Sciences, Kraków 2006.
Simić, S. (2007). Morphological and ecological characteristics of rare and endangered species Lemanea fluviatilis (Linné) C. Ag. (Lemaneaceae, Rhodophyta) on new localities in Serbia, Kragujevac Journal of Science, 29, pp. 97-106.

Starmach, K. (1977). Phaeophyta - Brunatnice, Rhodophyta - Krasnorosty, in: Flora stodkowodna Polski, Starmach, K. \& Siemińska, J. (Eds.). Polska Akademia Nauk, Warszawa \& Kraków 1977. (in Polish)

Vázquez, M.D., Fernández, J.A., López, J. \& Carballeira, A. (2000). Effects of water acidity and metal concentration on accumulation and within-plant distribution of metals in the aquatic bryophyte Fontinalis antipyretica, Water, Air, and Soil Pollution, 120, pp. 1-19.

Vazquez, M.D., Wappelhorst, O. \& Markert, B. (2004). Determination of 28 elements in aquatic moss Fontinalis antipyretica Hedw. and water from the upper reaches of the river Nysa $(\mathrm{Cz}, \mathrm{D})$ by ICP - MS, ICP - OES and AAS, Water, Air, and Soil Pollution, 152, pp. 153-172.

Vis, M.L. \& Sheath, R.G. (1992). Systematics of the freshwater red algal family Lemaneaceae in north America, Phycologia, 31, pp. 164-179.

\title{
Bioakumulacja metali ciężkich w makrofitach submersyjnych górskiej rzeki Białej Lądeckiej (Polska, Sudety)
}

\begin{abstract}
Streszczenie: Badania przeprowadzono na górskiej rzece Białej Lądeckiej. Pod względem hydromorfologicznym i zagospodarowania zlewni jest ona porównywalna $\mathrm{z}$ wieloma europejskimi rzekami górskimi. Celem pracy było określenie współczynników biokoncentracji metali ciężkich ( $\mathrm{Pb}, \mathrm{Cd}, \mathrm{Hg}, \mathrm{Ni}, \mathrm{Cr}, \mathrm{Cu}$ i Zn) w Ranunculus aquatile (L.) Dumort., Fontinalis antipyretica (L. ex Hedw.) i Lemanea fluviatilis (L.) C.Ag. Określono zawartość metali w wodzie, osadzie, i roślinach zanurzonych. Stężenia metali w roślinach można uszeregować w następujący sposób: $\mathrm{Hg}<\mathrm{Cd}<\mathrm{Cr}<\mathrm{Ni}<\mathrm{Cu}<\mathrm{Pb}<\mathrm{Zn}$. Najwyższe stężenia $\mathrm{Hg}$, Ni, $\mathrm{Cr}$ i $\mathrm{Cu}$ stwierdzono w $F$. antipyretica, a najwyższe stężenie $\mathrm{Pb}, \mathrm{Cd}$ i $\mathrm{Zn} w \mathrm{R}$. aquatile. Stężenia metali w $L$. fluviatilis zawsze były najniższe. Na podstawie zawartości metalu w wodzie i w roślinach obliczono współczynniki biokoncentracji (BCFs). Współczynniki BCFs były najniższe dla $L$. fluviatilis a najwyższe dla $F$. antipyretica. Spośród analizowanych metali, rośliny kumulowały najwięcej Zn a najmniej Hg. BCFs dla Zn wynosiło od 24111 (w L. fluviatilis) do 97574 (w R. aquatile), a BCFs dla Hg wynosiło od 29 (w R. fluviatilis) do $226 \mathrm{w}$ (F. antipyretica).
\end{abstract}

